\title{
Pandemi Covid-19: Momentum Introspeksi Tatanan Kehidupan Beragama Dalam Stagnasi Pariwisata
}

\section{Putu Sabda Jayendra \\ Kadek Ayu Ekasani}

\section{Ringkasan}

Perkembangan sektor pariwisata tidak bisa dilepaskan dari potensi budaya yang dimiliki masyarakatnya. Bali sebagai salah satunya merupakan destinasi yang difavoritkan secara global selama bertahun-tahun. Dinamika pariwisata di Bali tidak dapat dipisahkan dari eksistensi budayanya yang terkenal dan mendunia hingga ke mancanegara. Budaya Bali yang ikonik dan sangat kental dijiwai oleh agama Hindu menjadikannya daya tarik tersendiri yang mengundang wisatawan untuk datang dan menikmatinya.

Kodhyat (dalam Sumadi, 2012:11) menyatakan bahwa pada awal perkembangan pariwisata di dunia ditandai dengan aktivitas perjalanan (travelling) atau petualangan seseorang ke tempat-tempat yang disenangi dengan berbagai tujuan, seperti melaksanakan ibadah agama, perdagangan, memenuhi rasa ingin tahu, tujuan rekreasi, melaksanakan suatu misi, atau tujuan edukatif. Pariwisata di Bali secara hakikat tidak sekedar menjadi ajang promosi, namun juga mensosialisasikan sekaligus mengedukasi para wisatawan tentang seluk-beluk budaya Bali yang bersifat religius. Peraturan Daerah Bali No. 3 Tahun 1974 yang telah diperbaharui menjadi Perda No. 3 Tahun 1991 menjelaskan; Kepariwisataan yang dikembangkan di Bali adalah "Pariwisata Budaya", satu jenis kepariwisataan yang bertumpu pada kebudayaan Bali yang dijiwai Agama Hindu. Dalam pasal 1 ditegaskan Pariwisata Budaya adalah jenis kepariwisataan yang dalam perkembangan dan pengembangannya menggunakan Kebudayaan Daerah Bali yang dijiwai oleh Agama Hindu yang 
merupakan bagian dari kebudayaan nasional sebagai potensi dasar yang dominan, yang di dalamnya tersirat satu cita-cita akan adanya hubungan timbal balik antara pariwisata dan kebudayaan sehingga keduanya meningkat secara serasi, selaras, dan seimbang (Jayendra, 2019: 135).

Tentu saja hal ini merupakan suatu hal yang positif, namun bagaikan dua sisi mata uang, ada pula implikasi negatif dari perkembangan pariwisata tersebut. Tatanan kehidupan beragama dan berbudaya yang selama ini sudah mapan mulai tergerus ke ranah sekuler yang lazimnya disebut sebagai komodifikasi.

\section{Komodifikasi}

Mosco (dalam Susanti dan Rochman, 2016: 204) mengemukakan komodifikasi sebagai proses mengubah nilai pada suatu produk yang tadinya hanya memiliki nilai guna kemudian menjadi nilai tukar (nilai jual) dimana nilai kebutuhan atas produk ini ditentukan lewat harga yang sudah dirancang oleh produsen. Konsep komodifikasi sendiri sebenarnya merupakan teori yang banyak dipengaruhi oleh perspektif Marxisme. Piliang (dalam Dewi, 2016) menyatakan bahwa komodifikasi berasal dari kata komoditas,dan Marx memberi makna segala yang diproduksi dan diperjual belikan. Komodifikasi (commodification) adalah sebuah proses menjadikan sesuatu yang sebelumnya bukan komoditi, sehingga menjadi komoditi. Pada dasarnya komodifikasi merupakan sesuatu yang dimodifikasi sehingga menjadi bernilai komoditi.

Komodifikasi memiliki pengaruh yang sangat besar terhadap tatanan beragama dan berbudaya yang selama ini sudah dipandang mapan, terlebih jika kemapanan tersebut diukur berdasarkan nilai kesakralan. Masyarakat terpecah dalam 2 kategori, yakni kaum konservatif dan kaum progresif. Kalangan konservatif menilai bahwa komodifikasi menyebabkan terjadinya shock culture, perubahan dari ranah sakral menjadi profan, serta pengaburan garis demarkasi antara ranah sakral dan spiritual dengan ranah sekuler. Sedangkan kaum progresif menilai bahwa 
komodifikasi merupakan salah satu jalan untuk mengglobalisasi kearifan lokal.

Komodifikasi kebanyakan terjadi akibat perubahan orientasi budaya material yang lebih cepat diterima daripada budaya non material. Pemahaman nilai-nilai agama pada akhirnya mengalami ambivalensi akibat dinamika yang saling tarikmenarik. Komodifikasi yang terjadi seringkali berupa komodifikasi konten sajian yang diadaptasi dari unsur-unsur budaya yang dijiwai nilai agama Hindu yang kembali disesuaikan dengan selera pasar (wisatawan).

Untuk di Bali, pemanfaatan unsur budaya ini meliputi kesenian tradisi, adat istiadat serta ritual pada sistem religi (Widana, 2017). Seperti misalnya kesenian yang dahulunya merupakan suatu kegiatan yang bersifat sakral tanpa ada unsur komersial, kini berkembang menjadi kesenian yang memiliki daya jual untuk meningkatkan pendapatan secara ekonomi (Suardana, dkk 2015). Kebutuhan komodifikasi budaya ini adalah untuk memenuhi permintaan pasar (wisatawan) sebagai subyek yang melakukan kegiatan pariwisata. Berbagai macam jenis produk komodifikasi budaya sudah tersebar pada masing-masing daya tarik wisata maupun akomodasi perhotelan yang ada di Bali. Beberapa contoh jenis komodifikasi budaya tersebut seperti Tari Barong, Tari Sanghyang, dan lain sebagainya.

Aspek-aspek yang dikomodifikasi biasanya meliputi tempat, waktu, tujuan penyelenggaraan, dan atribut atau peralatan yang dipergunakan. Sebagai contoh antara lain:

1. Tempat, misalnya kesenian sakral tersebut hanya boleh dipentaskan di tempat suci atau pura, maka kini dipentaskan di hotel.

2. Waktu, misalnya kesenian sakral tersebut hanya boleh dipentaskan pada hari-hari yang dianggap suci, namun kini menyesuaikan dengan request tamu.

3. Tujuan penyelenggaraan, misalnya jika tujuan awalnya memohon keselamatan, berkah kesuburan, dan 
penghormatan pada Tuhan atau para dewa, kini digantikan oleh tujuan memuaskan para wisatawan.

4. Atribut atau peralatan yang digunakan, misalnya jika semestinya yang dipergunakan adalah atribut sakral seperti topeng atau tapel yang dikeramatkan, maka kini diganti dengan tapel yang tidak sakral.

Komodifikasi rentan menyebabkan pengaburan makna ideologis. Nilai-nilai filosofis sebagai budaya non material yang diwariskan secara turun-temurun pada akhirnya kalah cepat dengan penerimaan budaya material, karena segala sesuatunya dipandang dapat dimodifikasi sebagai komoditi.

\section{Covid-19 dan Stagnasi Pariwisata}

Pandemi Covid-19 yang merebak pada awal tahun 2020 menjadi kasus luar biasa yang akhirnya dinyatakan sebagai pandemi global. Berbagai sektor kehidupan terkena imbasnya, bahkan sektor yang mengalami pukulan cukup berat adalah pariwisata. Kebijakan lockdown di beberapa negara dan PSBB (Pembatasan Sosial Berskala Besar) di berbagai wilayah Indonesia praktis memuat aktivitas travelling terhenti dan aktivitas pariwisata mengalami stagnasi.

Stagnasi dapat diartikan sebagai macet, terhenti, tidak bergerak, tidak aktif, atau tidak jalan, yang dalam konteks ini cukup tepat menggambarkan kondisi pariwisata saat ini. Badan Pusat Statistik Provinsi Bali menyebutkan, ekonomi Bali dalam dalam tiga bulan pertama (triwulan I) 2020 tumbuh negatif, yakni $-1,14$ persen, dibandingkan kondisi tahun lalu pada triwulan I 2019. Pertumbuhan minus ini di luar kebiasaan dan diduga sangat dipengaruhi merebaknya wabah virus Covid 19 yang mempengaruhi pergerakan masyarakat secara individu maupun secara sosial. BPS Provinsi Bali melaporkan, jumlah kedatangan wisatawan mancanegara yang langsung ke Bali pada Maret 2020 sebanyak 156.876 kunjungan. Jumlah kunjungan selama Maret 2020 itu turun sedalam 56,89 persen dibandingkan jumlah 
kedatangan wisman selama Februari 2020 yang tercatat sebanyak 363.937 kunjungan. Penurunan pada sektor pariwisata diyakini berdampak domino terhadap lapangan usaha lainnya yang juga mengalami penurunan. Bahkan, tekanan terhadap ekonomi Bali pada triwulan I (Januari-Maret) 2020 digambarkan paling keras dan paling dalam selama empat tahun terakhir sejak 2017 (Paramita dan Putra, 2020).

Kondisi ini turut menyebabkan aktivitas promosi budaya untuk kepentingan pariwisata menjadi terhambat. Berbagai pertunjukan seni yang tidak digelar praktis membuat senimanseniman yang biasanya unjuk kebolehan seolah kehilangan pencahariannya. Kalaupun ada masih dilakukan dengan skala yang amat sangat terbatas dan ada pula yang digelar secara virtual.

Bali menjadi daerah yang paling merasakan dampak dari stagnasi pariwisata. Stagnasi pariwisata akibat pandemi global membuat masyarakat terjebak pada dua pilihan. Pertama, tidak bekerja atau dirumah saja dengan prioritas mengurangi resiko paparan Covid-19, namun ekonomi keluarga tidak berputar atau kedua, tetap bekerja demi perputaran ekonomi harian keluarga namun beresiko terpapar (Jayendra, 2020). Prioritas untuk survive dalam hal pemenuhan kebutuhan rumah tangga juga dilakukan dengan berbagai cara setelah mata pencaharian dalam sektor pariwisata tidak lagi dapat diandalkan.

\section{Introspeksi Tatanan Kehidupan Beragama}

Disisi lain, stagnasi pariwisata tidak dapat dipungkiri membuat timbulnya kerinduan akan euforia. Berbagai pertunjukan seni budaya yang sekaligus di jadikan promosi pariwisata secara tiba-tiba menjadi sepi. Bahkan kegiatan ritual upacara keagamaan pun digelar secara terbatas akibat adanya kebijakan social distancing dan physical distancing. Ritual-ritual keagamaan yang awalnya juga dimanfaatkan sebagai atraksi daya tarik wisata, kini masyarakatnya sendiri pun dibatasi secara kuantitas. Yang menjadi prioritas utama adalah kualitas upacaranya sendiri yang berorientasi pada tujuan pokoknya secara filosofis. 
Disadari atau tidak, hal ini secara tidak langsung sesungguhnya berdampak pada pengembalian fungsi dan nilai kesakralan yang hakiki dari pementasan seni dan budaya Bali. Pandemi Covid-19 jika dilihat secara positif, tentu merupakan momentum strategis dalam mengembalikan marwah atau spirit dari tatanan kehidupan beragama dan berbudaya tersebut. Artinya kebanggaan dalam beragama dan berbudaya bukan ditentukan karena promosi pada orang luar, melainkan memang karena hal tersebut merupakan identitas yang harus dijunjung bersama. Ada atau tidaknya pariwisata dalam sudut pandang kehidupan religi dan sosio-kultural semestinya bukan menjadi suatu ukuran dalam menentukan perlu atau tidaknya melestarikan tatanan kehidupan beragama.

Pandemi Covid-19 dapat dimaknai sebagai momentum untuk introspeksi terkait dengan tatanan kehidupan beragama yang telah banyak mengalami komodifikasi. Sebagai contoh, keberadaan pandemi Covid-19 "memaksa" untuk mulat sarira, introspeksi diri atas kealpaan terhadap esensi dari sakralnya suatu ritual. Ritual yang dilaksanakan, hendaknya berorientasi pada keheningan hati dan pikiran, tulus untuk Ida Sang Hyang Widhi Wasa.

Menyederhanakan tingkatan upacara, serta tidak melibatkan banyak orang sebagai konsekuensi protokol kesehatan merupakan suatu bentuk adaptasi yang menuju pada perubahan kembali pada esensi ritual itu sendiri. Hal tersebut merupakan indikasi yang meskipun tanpa disadari telah mengarah pada fleksibilitas. Fleksibilitas yang lebih mengedepankan esensi daripada modifikasi, yang lambat laun akan menimbulkan perubahan sosial yang diawali dari bangkitnya kesadaran.

Perubahan sosial tidak dipungkiri sebagian berawal dari adanya konflik. Dalam kasus benturan antara kemapanan tatanan agama dengan kebijakan pemerintah yang menerapkan protokol pencegahan Covid-19, seringkali timbul riak-riak yang mengarah pada stigma negatif berujung konflik. Namun tanpa disadari, pertentangan tersebut lambat laun menghasilkan konsensus baru yang pada akhirnya disepakati. Coser (dalam Rofiah, 2016) 
menyatakan bahwa tidak selamanya konflik berkonotasi negatif. Sebaliknya, konflik memberikan fungsi positif dalam sosial masyarakat untuk untuk menyatukan kembali kelompokkelompok yang sedang mengalami konflik sosial. Karena dengan adanya konflik, berarti masing-masing individu maupun kelompok di dalam komunitas itu berjuang untuk membangun dialog untuk mempertahankan integritas atau kesatuan sebagai anggota komunitas teristimewa dengan kelompok lain yang berasal dari budaya yang berbeda dengan dirinya. Selain itu, konflik dapat merangsang hidup setiap kelompok untuk merubah cara pandang yang pesimistis menjadi optimis untuk bersatu dengan kelompok-kelompok lain.

Begitu pula dalam membudayakan fleksibilitas dalam konteks penyelenggaraan kegiatan keagamaan yang bersifat sakral. Adanya pandemi Covid-19 secara hakikat memiliki peranan dalam menyatukan berbagai cara pandang mengenai kewajiban umat Hindu di Bali dalam melaksanakan ritual. Implikasinya adalah tercipta suatu kesepakatan baru tentang tata cara yang lebih mengedepankan esensi, tanpa mengurangi makna, namun lebih disederhanakan. Bagi kalangan yang awalnya pro komodifikasi, melalui peraturan hukum yang bersifat "memaksa" dari pemerintah secara tidak langsung juga mau tidak mau akan menyesuaikan dengan tatanan yang baru. Penyederhanaan ritual dengan kembali pada esensi, mengurangi modifikasi, dan mengesampingkan hasrat sosial merupakan contoh bentuk perubahan yang terjadi. Hal yang diharapkan bahwa revitalisasi esensi filosofis tatanan baru tidak hanya berlangsung selama masa pandemi, namun tetap diimplementasikan secara berkesinambungan pasca pandemi. 


\section{Daftar Pustaka}

Dewi, A.P., 2016. Komodifikasi Tari Barong di Pulau Bali (Seni Berdasarkan Karakter Pariwisata). Panggung, 26 (3).

Jayendra, P.S., Sudarmawan, I.W.E. and Wijaya, N.S., 2019. Eksistensi Produk Pis Bolong Sebagai Media Edukasi Religiusitas Budaya Bali Bagi Wisatawan Di Desa Kamasan, Klungkung. Jurnal Ilmiah Hospitality Management, 9 (2), pp.134-145.

Jayendra, P.S., 2021. Nasionalisme Dalam Bayang-Bayang Pandemi Covid-19: Sebuah Refleksi Peran Public Relations Dalam Penguatan Nilai-Nilai Kebangsaan. Makalah dalam: Webinar Talkshow Nasionalisme di Masa Pandemi Covid-19, 14 Agustus 2020 di PERHUMAS Denpasar.

Paramita, I.B.G. and Putra, I.G.G.P.A., (2020). New Normal Bagi Pariwisata Bali Di Masa Pandemi Covid 19. Pariwisata Budaya: Jurnal Ilmiah Agama Dan Budaya, 5 (2), pp.5765.

Rofiah, K., 2016. Dinamika Relasi Muhammadiyah dan NU Dalam Perspektif Teori Konflik Fungsional Lewis A. Coser. Kalam, 10(2), pp.469-490.

Suardana, G., Putra, I.N.D. and Atmaja, N.B., 2018. "The Legend of Balinese Goddesses": Komodifikasi Seni Pertunjukan Hibrid dalam Pariwisata Bali. Jurnal Kajian Bali (Journal of Bali Studies), 8 (1), pp.35-52.

Sumadi, I.K., 2012. Bali Dan Pariwisata Dalam Perspektif Teori Hegemoni. dalam Jurnal Pangkaja, 13.

Susanti, D. and Rochman, K.L., 2016. Analisis terhadap Komodifikasi Tubuh Perempuan Dalam Iklan Es Krim Magnum Versi Pink \& Black. Komunika: Jurnal Dakwah dan Komunikasi, 10 (2), pp.201-218.

Widana, I.G.K., 2017. Pemanfaatan Simbol Suci Hindu dalam Industri Pariwisata Bali. Dharma Smerti: Jurnal Ilmu Agama dan Kebudayaan, 17 (1), pp.102-110. 